\title{
A BICICLETA COMO MODAL DE TRANSPORTE SUSTENTÁVEL PARA A CIDADE DE SÃO PAULO: O ESTUDO DE CASO DA TRILHA NORTE-SUL
}

\author{
BICYCLE AS A SUSTAINABLE URBAN TRANSPORTATION MODAL IN THE \\ CITY OF SÃO PAULO: THE STUDY CASE OF NORTH-SOUTH TRAIL
}

\author{
CaRme Machí \\ Arquiteta Urbanista pela UPV-Valencia, Mestre em Urbanismo e Estrategia Territorial pelas \\ Faculdades de UPC-Barcelona, IUAV-Venice,KU-Leuven. \\ e-mail: machi.carme@gmail.com
}

MARcela Alonso

Arquiteta e Urbanista pela Universidade Presbiteriana Mackenzie, Pós Graduada em "Diseño y Arquitectura en el Marco de la Cooperación Internacional" pela Escola Superior de Disseny Elisava/Espanha e Cujae/Cuba e Especialista em Sustentabilidade das Edificações pela Universidade Presbiteriana Mackenzie e-mail: marcela0811@gmail.com

\section{VALÉRIA RUCHTI}

Arquiteta e Urbanista pela Universidade Presbiteriana Mackenzie. Mestre em Arquitetura e Urbanismo pela FAUUSP. Atuação e docência na área de arquitetura e urbanismo, história e paisagismo. e-mail: valeriaruchti@gmail.com

\section{RESUMO}

Durante o desenvolvimento urbano da cidade de São Paulo, tem se atribuído um papel dominante ao automóvel como modal prioritário no sistema de mobilidade urbana, fato que acarretou prejuízos ao meio ambiente, a desqualificação do espaço público e a marginalização do pedestre no ambiente urbano. Até pouco tempo, a cidade de São Paulo nunca tinha experimentado um incremento tão alto na representatividade da bicicleta como meio de transporte. Conforme a Pesquisa da Origem e Destino da Companhia do Metropolitano de São Paulo - Metrô, entre 1997 e 2007 as viagens utilitárias de bicicleta aumentaram cerca de $200 \%$ dentro do município. Neste contexto, o artigo avalia a alternativa de integrar o uso da bicicleta ao sistema de mobilidade urbana de São Paulo como uma das soluções possíveis para os problemas comentados anteriormente e explorará a viabilidade desses programas como forma de lidar com as problemáticas da paisagem urbana, utilizando-se da Infraestrutura Verde como conceito norteador.

Palavras-chave: Mobilidade Urbana; Infraestrutura Verde; Qualidade de Vida. 


\begin{abstract}
During the urban development of the City of São Paulo, it has been assigned a dominant role to the car as a priority in modal urban mobility system, a fact that caused damages to the environment, disqualification of public spaces and marginalization of the pedestrian in the urban environment. Until not long ago, the city of São Paulo had never experienced such a high increase in the representation of bicycles as a transportation mean. According to the Research of Origin and Destination, carried by the Companhia do Metropolitano de São Paulo - Metro between 1997 and 2007, the utility bicycle trips inside the city increased by $200 \%$. In this context, the present work evaluates the alternative of integrating the use of bicycles to the urban mobility system of São Paulo as one of the possible solutions to the problems previously discussed and explore the feasibility of these programs as a way of dealing with the problems of the urban landscape, by using the Green Infrastructure as a guiding concept.
\end{abstract}

Keywords: Urban Mobility; Green Infrastructure; Quality of Life.

\title{
INTRODUÇÃO
}

Durante as últimas décadas, tem se registrado um intenso movimento migratório da populaçao rural aos núcleos urbanos, principalmente nos paises considerados como emergentes ${ }^{1}$. Conforme as estatísticas do Banco Mundial de Desenvolvimento Urbano, mais do $90 \%$ do crescimento populacional destes paises acontece nas cidades ${ }^{2}$. Isso justifica o desefreado desenvolvimento de metrópoles que, em poucos anos, passaram a ocupar as primeiras posições nos rankings mundiais de população urbana. Este fenômeno pode ser constatado, por exemplo, na cidade de São Paulo que figura como quarta colocada na tabela das Naçoes Unidas (2015).

Estudos do Banco de Desenvolvimento da América Latina (2014) explicam que, junto ao fenômeno de crescimento da população urbana, aconteceu uma intensa expansão no território das cidades como consequencia da adoção de um modelo de ocupação

\footnotetext{
1 Classificação que o Fundo Monetário Internacional daria aos países em condição de desenvolvimento econômico, entre os que se inclui o Brasil

2 Disponível em: http://www.bancomundial.org/temas/cities/datos.htm Acesso em: 4 de Julho 2015
} 
mais dispersa e fragmentada. Além disso, nas décadas passadas, o planejamento urbano concedeu ao automóvel uma condição privilegiada no sistema viário, relegando ao transporte público e aos modais não-motorizados uma posição desfavorcida.

$\mathrm{Na}$ atualidade, como revelam os estudos realizados pelo Observatório da Mobilidade Urbana (OMU), centros importantes da América Latina padecem de problemas crônicos de congestionamento. Ademais, o transporte motorizado acarretou grandes impactos ambientais. Segundo dados do Painel Internacional de Mudanças Climáticas (IPCC, 2014, na sigla em inglês), esta é considerada uma das maiores fontes dos gases do efeito estufa na atmosfera, com índices estimados em $23 \%$ do total das emissões de $\mathrm{CO}_{2}$ globais. Conforme explica o Painel, uma das principais ferramentas para a redução destas emissões é a substituição do transporte motorizado individual ou público, em distâncias menores que $5 \mathrm{~km}$, por transportes não-motorizados como a caminhada e a bicicleta. Neste sentido, infraestruturas adequadas para bicicletas e pedestres podem incrementar em até $20 \%$ este tipo de viagens (IPCC, 2014, p.624). O informe também aponta a priorização de modais alternativos ao veículo privado como solução que pode aliviar o congestionamento massivo do sistema viário e permitir uma melhor oferta de transporte aos setores da população sem acesso ao carro.

Frente a todos estes dados, o presente artigo examina a implantação de uma ciclovia entre dois pontos verdes de importância significativa para a cidade, como forma de oferecer uma mobilidade urbana mais sustentável na cidade de São Paulo. Seu objetivo é discutir o uso da bicicleta como estratégia para o aumento da representatividade de modais não-motorizados, vislumbrando seu potencial para atingir ganhos socioeconômicos e ambientais.

Caberá, também, apontar carências e vulnerabilidades que dificultam a inserção da bicicleta, levando em conta a disposição atual do ambiente urbano, muitas vezes inóspita para pedestres e ciclistas. Nesse ponto de vista, serão ressaltadas questões socioambientais ligadas aos benefícios do transporte não poluente, como por exemplo: a melhora da paisagem, a preservação dos recursos naturais e a qualidade do ar, utilizando os princípios da Infraestrutura Verde como articuladora para um sistema integrado ao Planejamento Ambiental da cidade.

Assim, delineamos o potencial para uma "Trilha Norte-Sul" que cruza a mancha urbana e conecta o Horto Florestal ao Parque do Ibirapuera, avaliando sua viabilidade por meio de pesquisa de amostragem e de um levantamento sobre como a ciclovia pode integrar-se às bacias hidrográficas urbanizadas. 


\section{O PROBLEMA DA MOBILIDADE NA CIDADE DE SÃo PAULO E A QUEDA DA QUALIDADE DE VIDA NO AMBIENTE URBANO}

\section{A prioridade do veículo privado e os congestionamentos crônicos no trânsito}

Na maioria das grandes cidades latino-americanas, como São Paulo, Bogotá e Cidade do México, a ocorrência de um intenso fluxo migratório resultou no aumento acelerado da sua população, ocupando cada vez mais a periferia, de forma dispersa e segmentada, e desocupando progressivamente o centro (ULIAN, 2013). Ainda de acordo com Ulian (2013), entre os assuntos relacionados ao padrão demográfico que caracterizou essas cidades nas últimas décadas, podemos apontar, especificamente, os problemas de planejamento do transporte urbano que também derivam da precariedade das infraestruturas de mobilidade. Um agravante ainda maior é o uso preponderante do automóvel (VACARI, 2011).

Na cidade de São Paulo, registrou-se um aumento da frota incentivado pelos subsídios diretos, concedidos pelos governos federal e local, e pela melhoria salarial da população. Segundo o Relatório Sintese da Pesquisa de Mobilidade de $2012^{3}$ do Metrô, a frota de automóveis particulares cresceu $18 \%$ contra $8 \%$ do transporte nãomotorizado no período 2007-2012, resultando em uma taxa de motorização de 212 veículos por mil habitantes e no aumento expressivo das viagens de automóvel entre faixas intermediárias de renda mensal familiar. Com isso, a cidade sofreu um acréscimo significativo no volume de tráfego, enquanto o sistema viário tornouse incapaz de atendê-lo. Em resposta, a práxis tradicional de enfrentamento do congestionamento considera a ampliação da capacidade do sistema viário para o automóvel, acarretando fortes investimentos públicos para a construção de mais vias ou a expansão das existentes (VACARI, 2011).

No entanto, as experiências das últimas décadas demonstram que, com o tempo, tal direcionamento de capital na expansão da infraestrutura viária acaba, invariavelmente, sendo insuficiente e sujeito a uma demanda incessantemente maior. Essa estratégia, em vez de solucionar o problema, acaba por agravá-lo, como demonstra o aforismo do professor Badami, da Escola de Planejamento Urbano de Montreal: "Tentar curar o congestionamento adicionando mais capacidade de tráfego, é como tentar curar a obesida-

\footnotetext{
${ }^{3}$ Disponível em : < http://www.metro.sp.gov.br/metro/arquivos/mobilidade-2012/relatorio-sintese-pesquisamobilidade-2012.pdf> Acesso em: 5 de julho de 2015.
} 
de, soltando seu cinto." (DUANI, 2000). De fato, vários estudos realizados nesse campo revelam que, a médio e longo prazo, este parâmetro de atuação pode ser contraproducente (DUANI, 2000) e que o fenômeno do tráfego induzido e a chamada "demanda latente" indicam a necessidade de reformular o combate ao problema do trânsito.

Junto à ineficiência de tais ações na solução do congestionamento se somam os problemas ambientais, considerados de extrema relevância no contexto atual que privilegia alternativas mais sustentáveis, como as contidas no programa "As Cidades Somos Nós"(3), organizado pelo Institute for Transportation \& Development Policy (ITDP). A questão ambiental torna-se ainda mais relevante quando consideramos os dados do Painel Internacional de Mudanças Climáticas (IPCC, 2014, na sigla em inglês), que aponta o transporte como responsável por $23 \%$ das emissões de $\mathrm{CO}_{2}$ globais. O ITDP, em parceria com metrópoles como Cidade do México e São Paulo, destina parte dos seus esforços a incentivar estratégias para mitigar a utilização do automóvel particular, abrindo campo para modais alternativos. Desse modo, os novos modais tornamse uma questão central para a superação dos problemas de tráfego e trazem benefícios ambientais para as cidades (VACARI, 2011). De acordo com Taiyab (2008), o redirecionamento do paradigma do transporte urbano parte de uma mudança nas metas e não da insistência em soluções que, historicamente, sempre buscaram atender a demanda do veículo privado (DUANI, 2000).
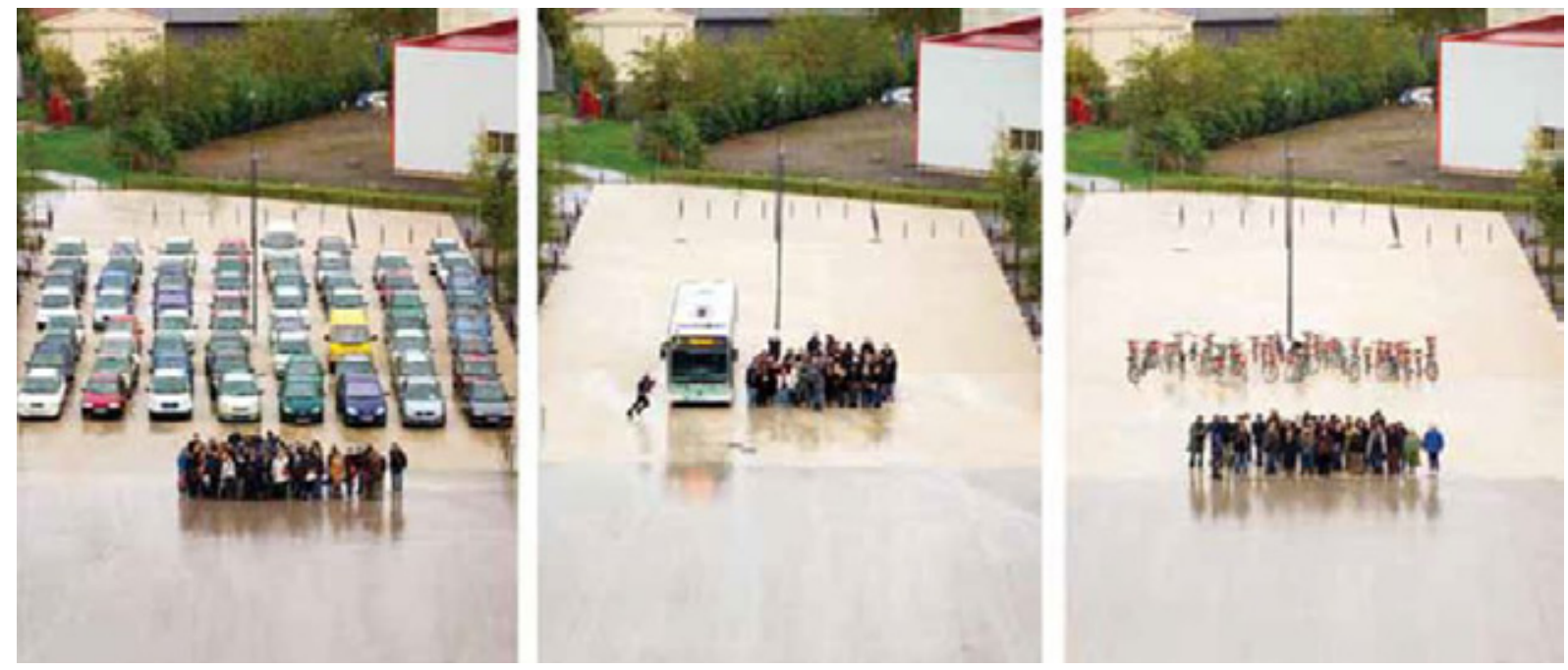

Figura 1 - Foto ilustrativa da capacidade dos modais em comparação com o espaço requerido para transportar 75 pessoas em 60 automóveis, 1 ônibus ou 75 bicicletas.

Fonte: Série de Cadernos Técnicos, 'Crise da mobilidade urbana na cidade de São Paulo' - São Paulo, 2013. ${ }^{4}$

\footnotetext{
${ }^{4}$ Disponível em: <http://www.ascidadessomosnos.org/>. Acesso em: 2 Junho 2015.
} 
A bicicleta e sua infraestrutura ocupam um espaço físico muito menor que o veículo particular. A implantação de ciclovias nas margens de córregos e rios pode gradualmente substituir faixas viárias impermeáveis por parques lineares ao longo do seu percurso, visando uma melhora na qualidade paisagística e ambiental.

A Infraestrutura Verde é uma ferramenta importante para o planejamento das ciclovias como indutora do equilíbrio entre a ocupação da cidade e os processos naturais.

\section{O histórico da bicicleta na cidade de São Paulo}

Frente à problematização exposta em relação ao contexto dessas cidades, vamos focar mais especificamente em São Paulo e na representatividade que teve o modal da bicicleta no seu histórico. Quanto a isso, é possível dizer que, culturalmente, o registro histórico da bicicleta como modal de transporte diário não foi significativo devido a topografia acidentada, clima instável, falta de infraestrutura cicloviária e tráfego agressivo, desmotivando o uso deste modal pelo paulistano (MALATESTA, 2014). Cabe comentar, segundo afirma Alcorta (2014), que a bicicleta teve maior representatividade como opção de transporte para os setores de baixa renda.

Na década de 1980, iniciaram-se os primeiros planos e programas para implantação da bicicleta como meio de locomoção, justificados pela crise do petróleo, pelas bem sucedidas experiências europeias e, de forma secundária, pela melhoria do meio ambiente. A diretriz destes primeiros planos foi definida pelo Ministério dos Transportes e desenvolvida pelo GEIPOT - Empresa Brasileira de Planejamento dos Transportes. Para divulgar este trabalho em vários municípios, foi publicada uma coletânea de manuais com instruções de projeto e planejamento cicloviários. Neste contexto, em dezembro de 1980 foi feito um estudo para ligar 7,7 Km entre a Cidade Universitária e o Parque do Ibirapuera, utilizando para o trajeto os canteiros centrais e calçadas das avenidas. Este projeto foi reformulado em 1994 devido às alterações sofridas nas avenidas Juscelino Kubitscheck e Waldemar Ferreira, mas não chegou a ser implantado. O primeiro plano de ciclovias para a Cidade de São Paulo foi elaborado em fevereiro de 1981 e denominado "Sistemas Cicloviários Setoriais". Na ocasião o plano não foi posto em prática, mas suas intenções foram consideradas posteriormente, como por exemplo, na ciclovia do canteiro central da avenida Sumaré, implantada em 1996.

A Lei Municipal n 10.907 de 18 de dezembro de 1990 e o seu decreto regulamentador 
$\mathrm{n}^{\circ} 34.854$ de 3 de fevereiro de 1995, instituíram a obrigatoriedade de incluir ciclovias nas novas avenidas. Segundo Malatesta (2014), foi instituído, em 1994, pela Prefeitura do Município de São Paulo, o Projeto Ciclista. Este foi o primeiro programa com o "objetivo de estabelecer as ações necessárias à implementação de infraestrutura urbana e educativa para o conforto, segurança e economia do cidadão ciclista". A coordenação e a orientação das diretrizes orçamentárias para implementação do Projeto Ciclista foram atribuídas à Secretaria Municipal do Verde e Meio Ambiente - SVMA. No mesmo ano, foi desenvolvido um Plano de Ciclovias para o município de São Paulo para ser incorporado a este projeto. O plano previa um estudo de percursos mais utilizados nos finais de semana para lazer, em especial os que acessavam os parques da cidade já consagrados pelo uso da bicicleta, como ação inicial para estimular o uso cotidiano e sensibilizar os motoristas e pedestres sobre o convívio com este modal. Outro dado que pode ser ressaltado no avanço da inclusão do modal é a observância das normas de trânsito por parte dos usuários da bicicleta a partir de 1997, com a criação do Código de Trânsito Brasileiro (CTB). O Projeto Ciclista considerava $110 \mathrm{Km}$ de ciclovias e ciclofaixas, mas apenas $32 \mathrm{Km}$ foram criados efetivamente, correspondendo a 6 ciclovias dentro de quatro parques municipais. Estas foram implantadas através de ações isoladas, sem uma coordenação geral vinculada a um programa específico (MALATESTA, 2014).

Porém, mesmo que a bicicleta tenha sido considerada nos programas, leis e normativas desde a década de 1980, somente a partir de 2005, de acordo com Malatesta (2007), foi consolidada como um modal de transporte único ou complementar, como consequência, em parte, da crescente preocupação com as condições ambientais e de mobilidade no município. Essa preocupação foi resultado do crescimento da frota veicular motorizada e dos congestionamentos, além da degradação do meio ambiente pela poluição do ar. Neste mesmo ano de 2005, a Prefeitura do Município de São Paulo criou o GT Bicicleta, coordenado conjuntamente pela SVMA - Secretaria Municipal do Verde e Meio Ambiente e pela SMT - Secretaria Municipal de Transportes, com participação do Governo do Estado e da sociedade civil organizada, com o objetivo de desenvolver um plano de intervenções cicloviárias. Esse grupo desenvolveu vários estudos para responder à Iniciativa do Ar Limpo para a América Latina do Global Environment Facility (GEF), administrado pelo Banco Mundial. A Iniciativa do Ar Limpo para a América Latina teve como premissa minimizar as emissões de gases de efeito estufa especificamente no setor de transportes, resultando no "Relatório de Grupo de Trabalho Interinstitucional para Estudar o Fomento do Uso da Bicicleta como Meio de Transporte Não-Motorizado e Instrumento de Melhoria Ambiental com Indicação de 
Áreas para Intervenção Piloto". Os estudos realizados pelo GT Bicicleta foram apresentados para as subprefeituras com o intuito de fomentar o uso da bicicleta como meio de transporte não-motorizado e instrumento de melhoria ambiental.

A inserção da bicicleta foi também favorecida pela implantação de bicicletários instalados em estações de Metrô e da Companhia Paulista de Trens Metropolitanos (CPTM). O primeiro estacionamento integrado funcionou entre 1984 e 1988 na estação Jandira, aberto a automóveis, motos e bicicletas. Nessa mesma época, também foram instalados estacionamentos para bicicletas nas estações Itapevi, Pinheiros e Jurubatuba. A CPTM retomou a iniciativa na década de 1990 com parceria dos municípios e presidiu a instalação de todos os bicicletários hoje existentes ao longo da malha da ferroviária. Além disso, foi disponibilizado o Bilhete Único, válido para os diversos tipos de modais, bem como os pontos de aluguel para bicicletas públicas favorecendo a intermodalidade.

Uma pesquisa de opinião realizada pela CET - Companhia de Engenharia de Tráfego - em março de 1992 junto aos usuários, aponta que 40\% deles usavam bicicleta. Destes, a maioria utilizava para lazer $(40,4 \%)$ e $14,4 \%$ para transporte regular (MALATESTA, 2014). Na Pesquisa de Origem e Destino do Metrô entre 2007 e 2012, constata-se uma participação muito pequena da bicicleta como modo principal, sem conexão com os modais motorizados, mas já com tendência de crescimento.

A partir da análise de todas estas informações, é possível constatar que, ao longo do tempo, as políticas para implementação de ciclovias na cidade de São Paulo foram fragmentadas e interrompidas por diversas vezes, não favorecendo a utilização do modal na cidade pela falta de infraestrutura e segurança. Contudo, pelo aumento espontâneo deste modal em meio aos carros, como alternativa para fugir dos congestionamentos e/ou por conscientização ambiental, a sociedade civil passou a reivindicar melhores condições de segurança para os ciclistas e essa pauta se tornou alvo importante nas discussões sobre o planejamento da cidade.

\section{Vulnerabilidades, enfrentamentos, vantagens e desvantagens da bicicleta}

Como já vimos, um dos maiores problemas na inserção da bicicleta é a cultura do automóvel (MALATESTA, 2014). Nessa perspectiva, é notável o despreparo na formação do motorista e do ciclista. Segundo o Relatório de Acidentes Fatais da CET 
em $2014,48,2 \%$ das fatalidades foram registradas entre pedestres $(38,8 \%)$ e ciclistas $(3,8 \%)$. A desigualdade na disputa pelo espaço viário deflagra os riscos com relação aos acidentes de trânsito.

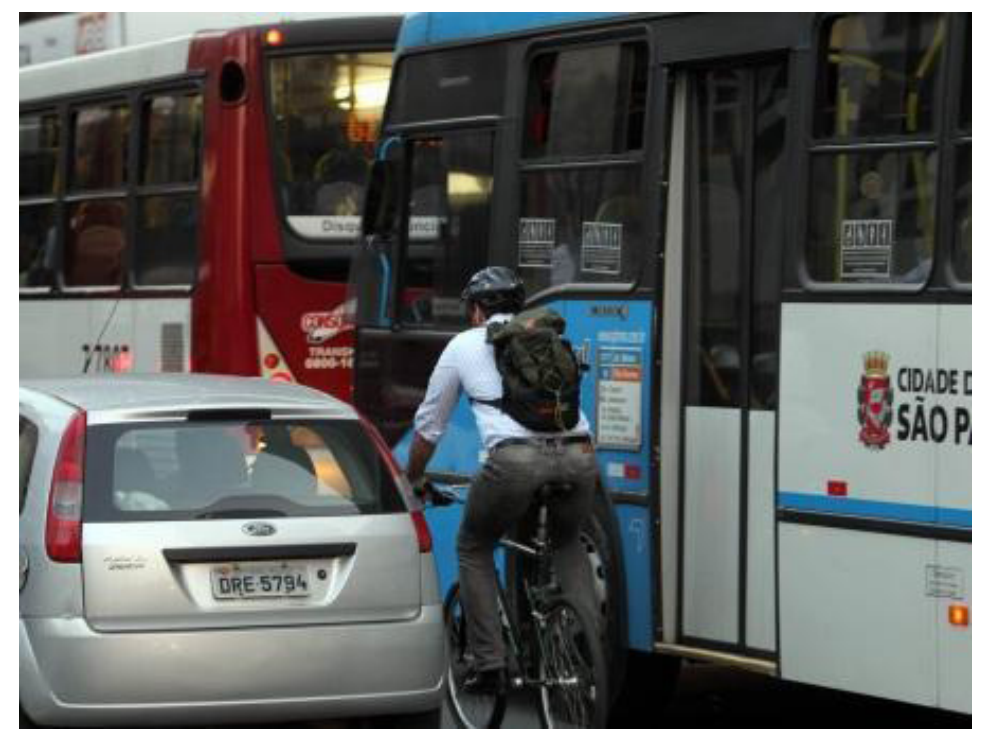

Figura 2 - Ciclista pedalando no trânsito de São Paulo Fonte: Agência Estado ${ }^{5}$

Em vista das necessidades de mudança nesse paradigma cultural, podemos citar o exemplo surpreendente da Holanda, onde a consolidação da rede ciclística teve que passar por grandes mudanças sociais. A economia holandesa apresentou crescimento significativo após a Segunda Guerra Mundial, o que possibilitou a aquisição de mais veículos privados. Em decorrência da perda de vidas por acidentes de trânsito estimada em 3.300 apenas no ano de 1971, das quais 400 eram crianças, ocorreram muitos protestos reivindicando vias mais seguras para pedestres e ciclistas, pois as ciclovias existentes eram estreitas, perigosas e desconectadas. O governo reconheceu a mudança de paradigma juntamente com a primeira crise do petróleo em 1973. Considerado atualmente o país mais seguro do mundo para pedalar e que possui o maior número de ciclistas, a Holanda obteve gradativamente uma cadeia de ciclovias de alta qualidade associando a mudança na consciência à forma de planejar a sua infraestrutura.

No mundo, foram extremamente interessantes os movimentos de cicloativistas para a defesa deste modal nas grandes cidades, que passaram a acontecer também no Rio de Janeiro e em São Paulo, ainda na década de 80. Entre esses grupos, podemos

5 Disponível em : <http://noticias.r7.com/sao-paulo/noticias/diario-oficial-diz-que-ciclistas-nao-devem-pedalar-emsp-20120711.html>. (Foto Evelson de Freitas 2209 2010). 1107 2012. Acesso em: 15 maio 2015. 
citar os de passeios noturnos (Night Biker's Club) e os denominados World Naked Bike Ride, originados nos Estados Unidos. Tal movimento chegou a São Paulo na manifestação de ciclistas nus ocorrida em junho de 2008, na Avenida Paulista, representando uma metáfora da vulnerabilidade em meio a hostilidade do trânsito. O poder de mobilização de tais movimentos atrai a atenção da mídia e da sociedade, sendo um mecanismo fundamental para debater a criação de políticas públicas que priorizem a bicicleta e contemplem suas reivindicações por segurança (MALATESTA, 2014).

Na cidade de São Paulo, apontando os problemas e barreiras a serem enfrentados, é importante citar a carência de um planejamento que estruture e envolva todos os modais. Sejam eles por meio do transporte coletivo (ônibus, metrô), automóveis, motocicletas, bicicletas e caminhadas, é preciso contemplar todos em uma única grande malha viária em que o cidadão seja sempre o protagonista. Para Raquel Rolnik (2015), arquiteta e urbanista, professora da Faculdade de Arquitetura e Urbanismo da Universidade de São Paulo, ainda falta muito para São Paulo se reinventar.

Como principal limitação no traçado das redes cicloviárias, é necessário considerar as barreiras que supõem a presença de infraestruturas de grande porte, como viadutos, vias rápidas, ferrovias e rios canalizados. Essas grandes estruturas criam cicatrizes na malha urbana, de maneira que a ligação entre as partes precisa ser atendida através de transposições. Não obstante, muitas destas ligações são projetadas isoladamente para o uso de veículos motorizados, sem considerar ao usuário a pé ou em bicicleta. A cidade de São Paulo é cortada por dois rios principais, o Pinheiros e o Tietê, que constituem uma barreira natural na ligação Norte-Sul. Suas transposições foram pensadas para a circulação dos veículos, criando descontinuidades nos fluxos e maiores deslocamentos dos usuários mais vulneráveis. A meta para acessibilidade universal dentro da cidade precisa considerar essa premissa fundamental para a inserção real da rede cicloviária em São Paulo.

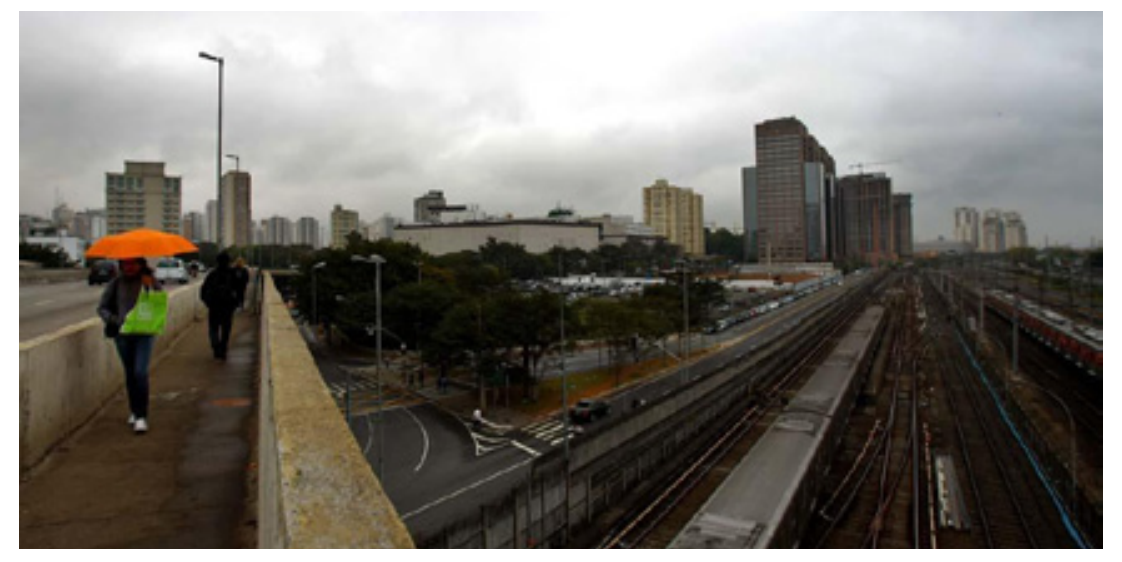

Figura 3 - Vista da pista segregada no viaduto Antártica para circulação de pedestres ou bicicleta.

Fonte: Foto Panoramio, Google Maps. 


\section{A BICICLETA COMO MAIS UM MODAL DE TRANSPORTE NO COTIDIANO PAULISTANO}

\section{Experiências bem sucedidas e projetos possíveis para o uso da bicicleta na Cidade de São Paulo}

Ao tratar de diversos assuntos relacionados à busca por um melhor modelo de sustentabilidade urbana, o Plano de Ação Greenest City 2020 para Vancouver definiu metas com relação à mobilidade urbana, como a diminuição das emissões de gases e do consumo de água e a geração de empregos em atividades com fins ecológicos. Além disso, contempla o aumento na representatividade da bicicleta, investindo no desenvolvimento da rede de ciclovias para chegar a $265 \mathrm{~km}$ no total, em uma cidade com pouco mais de 600 mil habitantes. A meta é que o uso da bicicleta atinja $50 \%$ sobre o total dos deslocamentos previstos até 2020 . Hoje, este modal representa $42 \%$ do total de deslocamentos na cidade. Evidencia-se, em relação à esta última previsão e em uma rápida comparação com São Paulo, a condição desigual no equipamento da cidade para uso deste modal, sendo que a população residente na área municipal, no caso de São Paulo, é de quase 12 milhões de habitantes, com apenas $289,6 \mathrm{Km}$ de ciclovias.
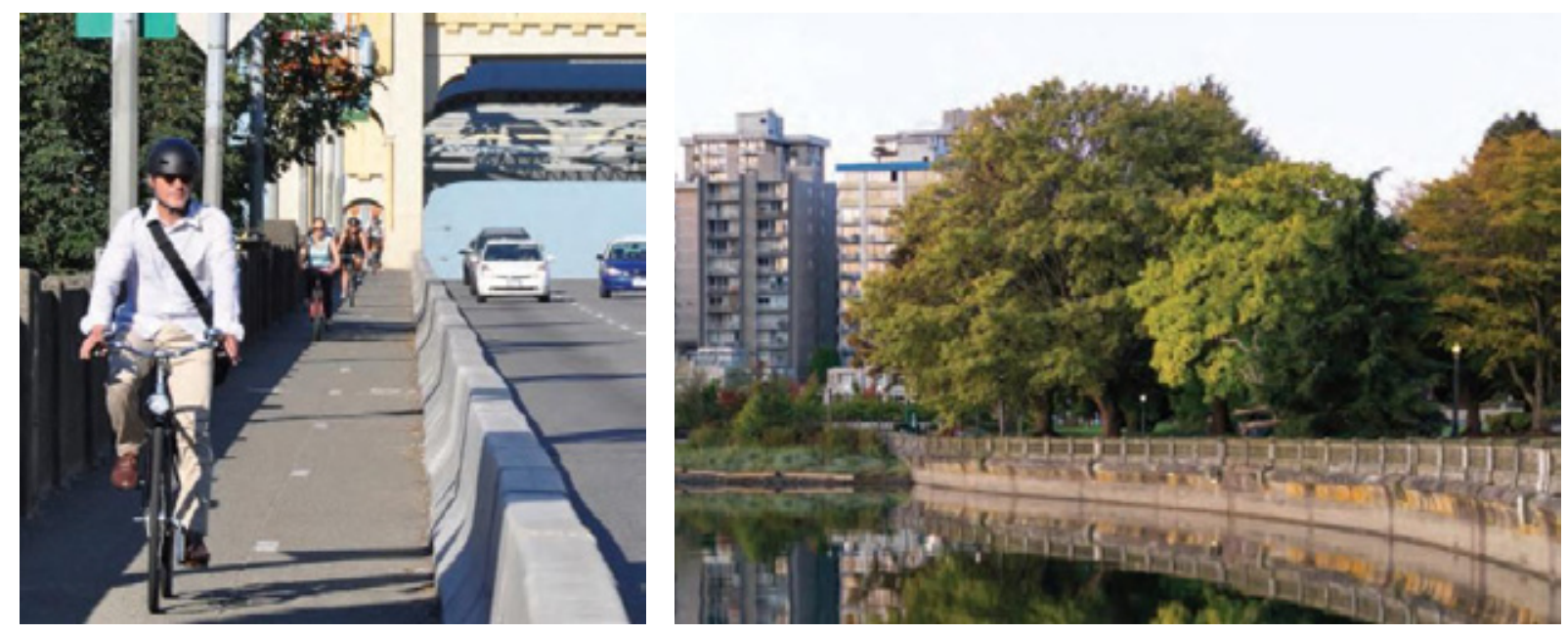

Figura 4 - Duas vistas na cidade de Vancouver, à esquerda mostrando a integração da bicicleta na transposição da ponte como transporte segregado dos veículos e à direita a conexão com sistemas verdes e espaços naturais.

Fonte: Programa 'Greenest City ActionPlan', Vancouver, 2014

Além disso, o Plano de Ação trata da implantação da rede cicloviária com uma visão conjunta, integrada à discussão da estruturação dos seus espaços verdes, acessibi- 
lidade aos equipamentos públicos e alternativas para lazer, esporte, ócio e cultura. Para tanto, entre as suas metas, este programa pretende melhorar a acessibilidade dos cidadãos a estas áreas identificando como medidas necessárias a implantação de Greenways ou vias verdes, que tornariam a cidade mais humanizada e adequada para caminhar. Esta medida trabalharia em conjunto com a expansão dos parques, zonas vegetadas e sistemas para pedestres e bicicletas, priorizando o acesso aos equipamentos públicos necessários.

Outra referência internacional que propõe estratégias verdes junto à reestruturação do sistema de mobilidade em bicicleta e a pé é o Plano para Nova York de 1993. Este plano desenvolveu o total de $563 \mathrm{Km}$ de vias ajardinadas e ofertou múltiplas oportunidades de ócio e lazer, junto com a melhora na mobilidade para os ciclistas e pedestres. Com isso, a rede se agrega a um sistema mais abrangente que responde tanto às necessidades de ganhos paisagístico-ambientais como às de segurança no espaço público.

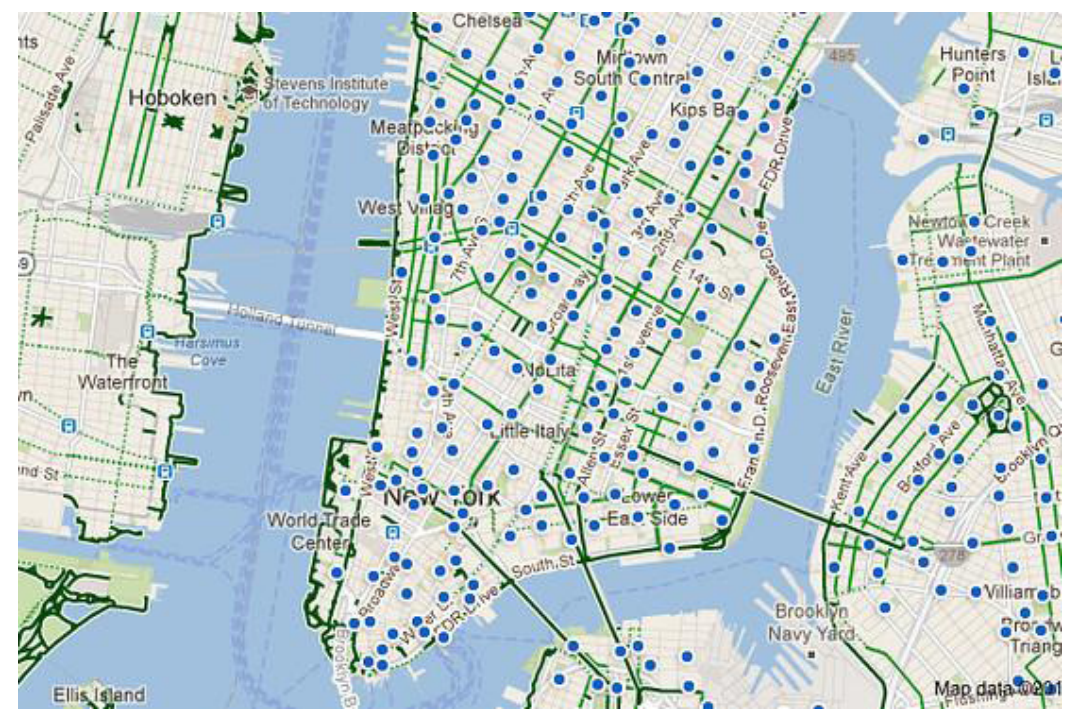

Figura 5 - Mapa da área de Manhattan, Brooklyn e Queens para projeto inicial de "bike-share" na cidade de Nova York.

Fonte: The Wall Street Jornal/NY ${ }^{6}$

Um bom exemplo de sucesso da implantação de ciclovias em terreno acidentado acontece na cidade de São Francisco, nos Estados Unidos. Nas pontes da cidade foram implantadas ciclovias para diminuir o uso do transporte motorizado. Devido ao seu relevo acidentado, como o de São Paulo, as ruas mais planas e rotas mais diretas foram privilegiadas no plano do sistema ciclístico da cidade. Nas ladeiras mais íngre-

6 Disponível em: <http://blogs.wsj.com/metropolis/2012/05/ 11/bike-share-map-shows-first-wave-of-stations/>. Acesso em: 15 maio 2015. 
mes, as ciclovias são mais largas para ajudar quem precisar empurrar a bicicleta. Alguns pontos terão elevadores para facilitar o transporte das bicicletas ladeiras acima.

Outra cidade que sofre com seu relevo acidentado é Trondheim, na Noruega. Isso, no entanto, não impede que $18 \%$ da população utilize a bicicleta como meio de transporte. Nas ladeiras, os ciclistas inserem o cartão de acesso na máquina que controla o "elevador" e colocam um dos pés no suporte metálico. Automaticamente, um sistema guiado por trilhos empurra a pessoa junto com sua bicicleta ladeira acima, a uma velocidade que varia entre $4 \mathrm{~km} / \mathrm{h}$ e $5 \mathrm{~km} / \mathrm{h}$.

O plano diretor da Prefeitura de São Paulo prevê no ponto VI do Art. 25, subseção II, do Projeto Lei $n^{\circ}$ 16.050, 31 de Julho de 2014 "articular, através de caminhos de pedestres e ciclovias, preferencialmente nos fundos de vale, as áreas verdes significativas, os espaços livres e os parques urbanos e lineares". O mesmo plano cita a implantação do sistema cicloviário integrado ao de transporte público coletivo de alta e média capacidade. Com isso, as ciclovias devem ser conectadas a outros transportes coletivos que facilitem o acesso do usuário quando houver barreiras geográficas.

$\mathrm{Na}$ cidade de São Paulo, uma das soluções de baixo custo é dar preferência para implantação de ciclovias seguindo o fluxo de rios e córregos, as chamadas "trilhas verdes", já que suas bacias hidrográficas são repleta de nascentes e cursos d'água. Essa opção é uma das respostas possíveis a outro questionamento do paulistano sobre as ciclovias: o clima. Com as trilhas verdes é possível amenizar o calor, não somente com as sombras das árvores, mas também com a vaporização da água nos trechos onde as ciclovias passem por rios ou córregos a céu aberto e recuperados. Isto beneficiaria não só o ciclista, mas também a cidade como um todo, melhorando a qualidade do ar, aumentando a área verde, diminuindo da emissão de $\mathrm{CO}_{2}$ na atmosfera, com significativa melhora da paisagem urbana, entre outros benefícios.

As "trilhas verdes" já foram antes contempladas no "Concurso Nacional de Ideias para a Estruturação Urbana e Paisagísticas das Marginais dos Rios Pinheiros e Tietê", promovido pela PMSP e o IAB de São Paulo em 1998, através do trabalho elaborado por uma equipe multidisciplinar, liderada pela arquiteta paisagista Maria de Assunção Ribeiro Franco. Esta proposta prevê o afastamento das marginais expressas do leito dos rios, deixando uma via local e criando uma "via parque" onde circulariam apenas pedestres e bicicletas. Isto possibilitaria o surgimento de filtros verdes de purificação das águas superficiais (chuvas) e a promoção de atividades ligadas ao lazer, esporte 
e turismo. Desta forma, a bicicleta está ligada à promoção da mobilidade sustentável e à valorização do meio ambiente (Figura 06).

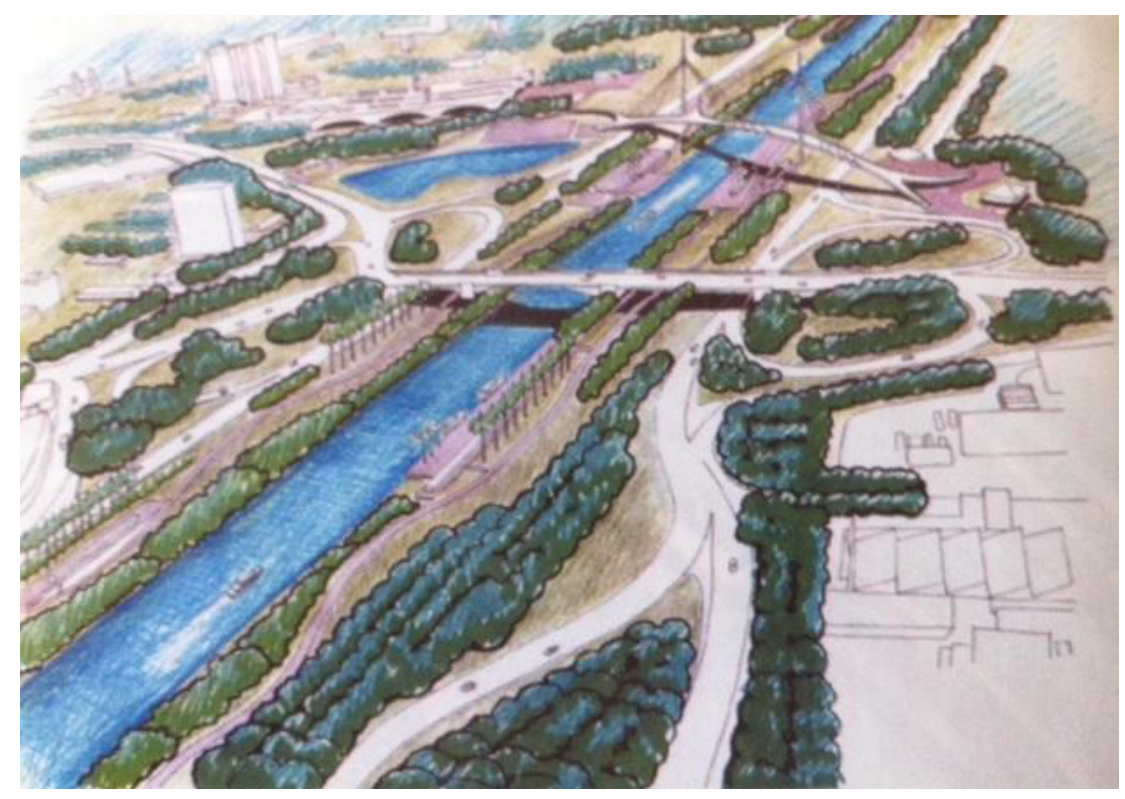

Figura 6 - APA Urbana - Tietê-Pinheiros: Trecho II - proposta perspectiva.

Fonte: Franco (2000, p. 276).

Outra referência de proposta mais recente, que contempla "trilhas verdes" e pontes com acesso à bicicleta e pedestres pelo rio Tietê, é um dos trabalhos apresentados na primeira fase do chamamento público para os Estudos de Pré-viabilidade do Arco Tietê promovido pela Prefeitura de São Paulo em 2013, do Consórcio Axal (Figura 07).

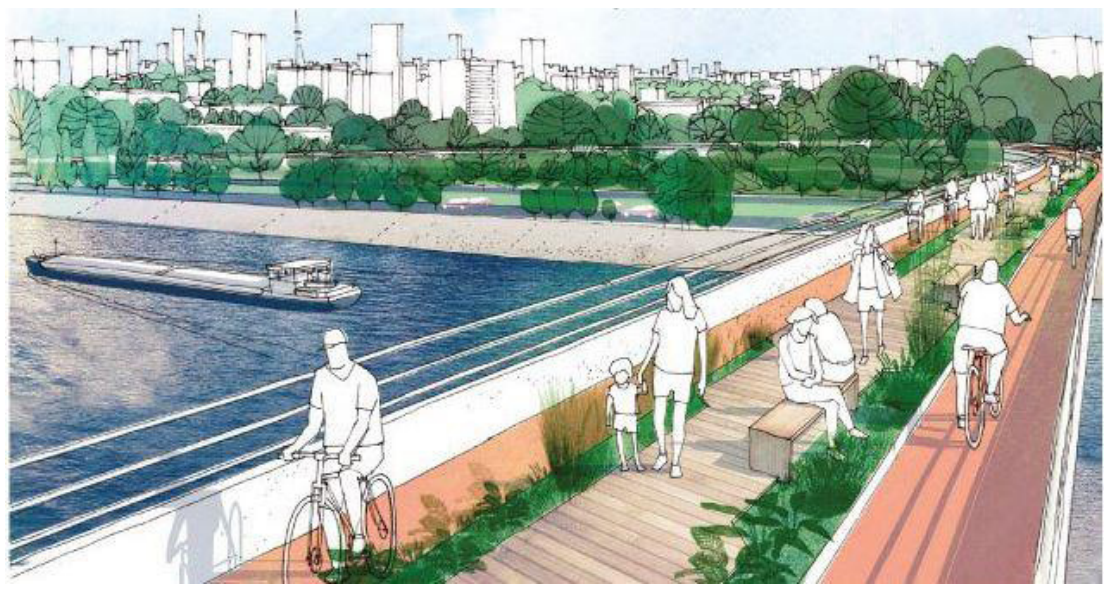

Figura 7 - Proposta do Consórcio Axal - Arco Tietê Fonte: página do Ciclo Vivo plantando notícias ${ }^{7}$

7 Disponível em: <http://ciclovivo.com.br/noticia/sp-pode-ter-marginal-subterranea-e-parque-linear-no-rio-tiete>. Acesso em: 13 maio 2015. 


\section{Amostragem sobre a implantação de ciclovias na cidade de São Paulo e a percepção do uso da Trilha Norte-Sul'}

A pesquisa feita para o presente estudo foi realizada em maio de 2015, presencialmente na Avenida Sumaré e via Internet. Foram selecionadas 30 pessoas, algumas das quais ciclistas, de ambos os sexos, com idades entre 19 e 76 anos. A escolaridade dos entrevistados vai desde o ensino fundamental à pós graduação e alguns residem na Grande São Paulo, mas todos trabalham na cidade. O objetivo foi, por meio de uma pequena amostragem, trazer uma aproximação com o cotidiano do paulistano para obter uma visão do cidadão sobre a implantação de ciclovias na cidade de São Paulo e a viabilidade da Trilha Norte-Sul.

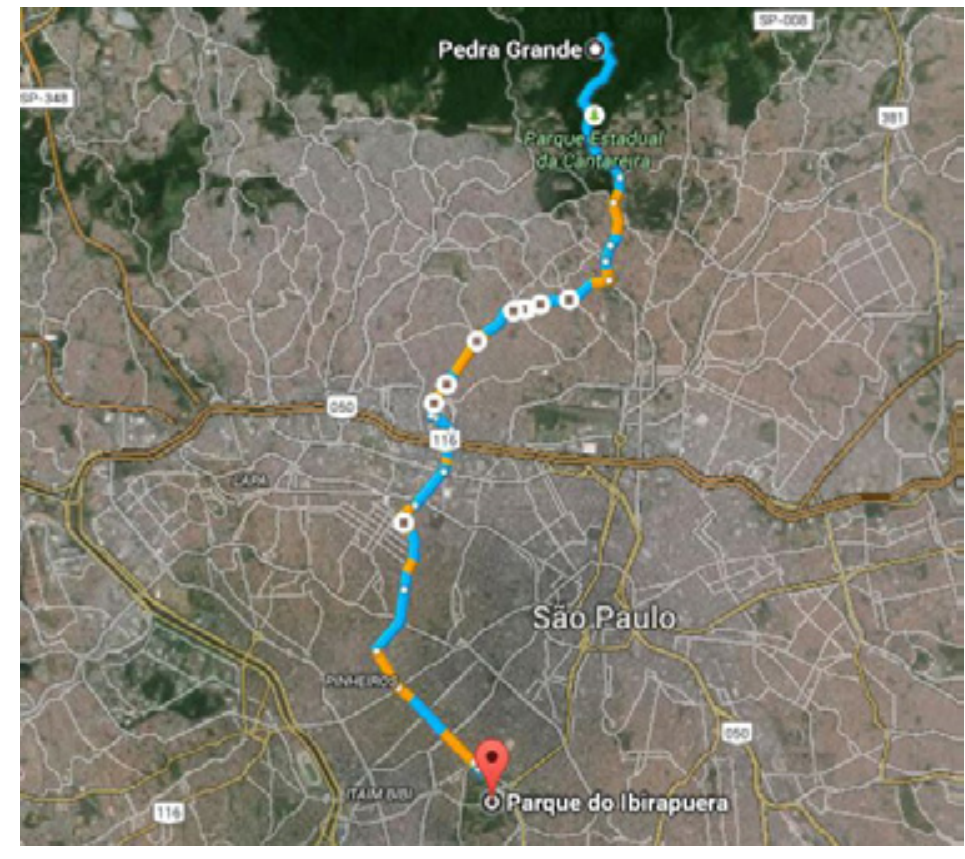

Figura 8 - Foto de satélite da Trilha Horto Florestal - Parque Ibirapuera Fonte: Elaboração dos autores em base no Google Earth, map data. Google, Digital Globe. Acesso em: maio, 2015.

Pela amostragem, podemos constatar que muitos já usam a bicicleta - 30\% para lazer e $17 \%$ como transporte regular. O pior impedimento verificado para o uso da bicicleta é o medo de acidentes. A maioria (96\%) é a favor da implantação das ciclovias e acha interessante uma conexão entre o Horto Florestal e o Parque do Ibirapuera. Quanto ao trecho mais complicado para o uso da bicicleta, $45 \%$ dos entrevistados elegeu o Tremembé-Mandaqui, ou seja, o trecho com relevo mais acidentado.

Tendo em vista a potencialidade do uso da Trilha Norte-Sul como elo de ligação entre duas áreas verdes significativas para a cidade e sua importância na recuperação am- 
biental, foi realizada, para este artigo, uma interpretação do percurso propondo uma alternativa viável à sua implantação e abrangendo uma faixa de 500 metros de entorno.

\section{Estudo de caso: Trilha Horto Florestal - Parque do lbirapuera}

O caso da Trilha Norte-Sul estuda como a inserção da bicicleta no espaço urbano traz benefícios para a qualidade de vida e socioambiental da cidade a partir da sua integração ao Planejamento Ambiental. Seria desejável, na construção da cidade e do próprio território, incluir essa visão mais integradora. Desta forma, a incorporação de sistemas de mobilidade urbana não poluente pode ser estudada em conjunto com outras medidas de Infraestrutura Verde para incentivar programas e ações que visem a melhoria do ambiente urbano como um todo.

É fundamental respeitar as singularidades topográficas e geomorfológicas desta cidade e a influência de suas bacias hidrográficas no raciocínio para o planejamento das novas infraestruturas cicloviárias.

A Trilha permeia a malha urbana da cidade e interliga os sistemas verdes com soluções que atendem as demandas do transporte urbano, seguindo, sempre que possível, o traçado dos córregos para aproveitar a topografia favorável.

O ponto de partida da "Trilha Horto Florestal - Parque do Ibirapuera" encontra-se na cota mais alta e afastada da malha urbana da cidade, mais precisamente na Pedra Grande, dentro do Horto Florestal. A trilha segue pela Avenida Santa Inês, atravessando a bacia do Tremembé e cruzando o córrego do Horto. Posteriormente continua pela Avenida Voluntários da Pátria até o encontro da Avenida Caetano Álvares e percorre o curso do córrego Mandaqui em direção ao rio Tietê. No primeiro trecho da Avenida Caetano Álvares, o córrego está canalizado e fechado e já existe um tratamento paisagístico com ciclovia. No segundo trecho, o córrego está a céu aberto e a ciclovia existente é estreita, limitada por uma mureta de contenção e continua com tráfego intenso até encontrar a várzea do Tietê. 

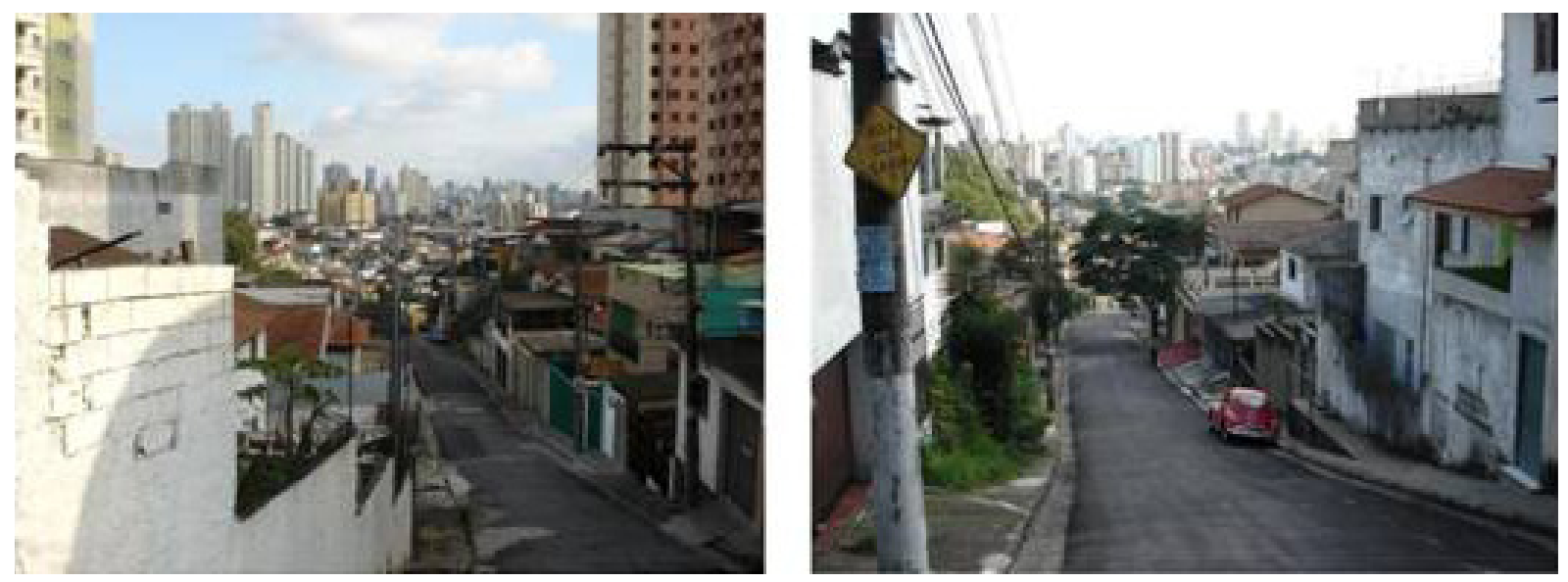

Figura 9 - Vistas da Rua Santa Inês. Fonte: Fotos Panoramio, Google Maps.
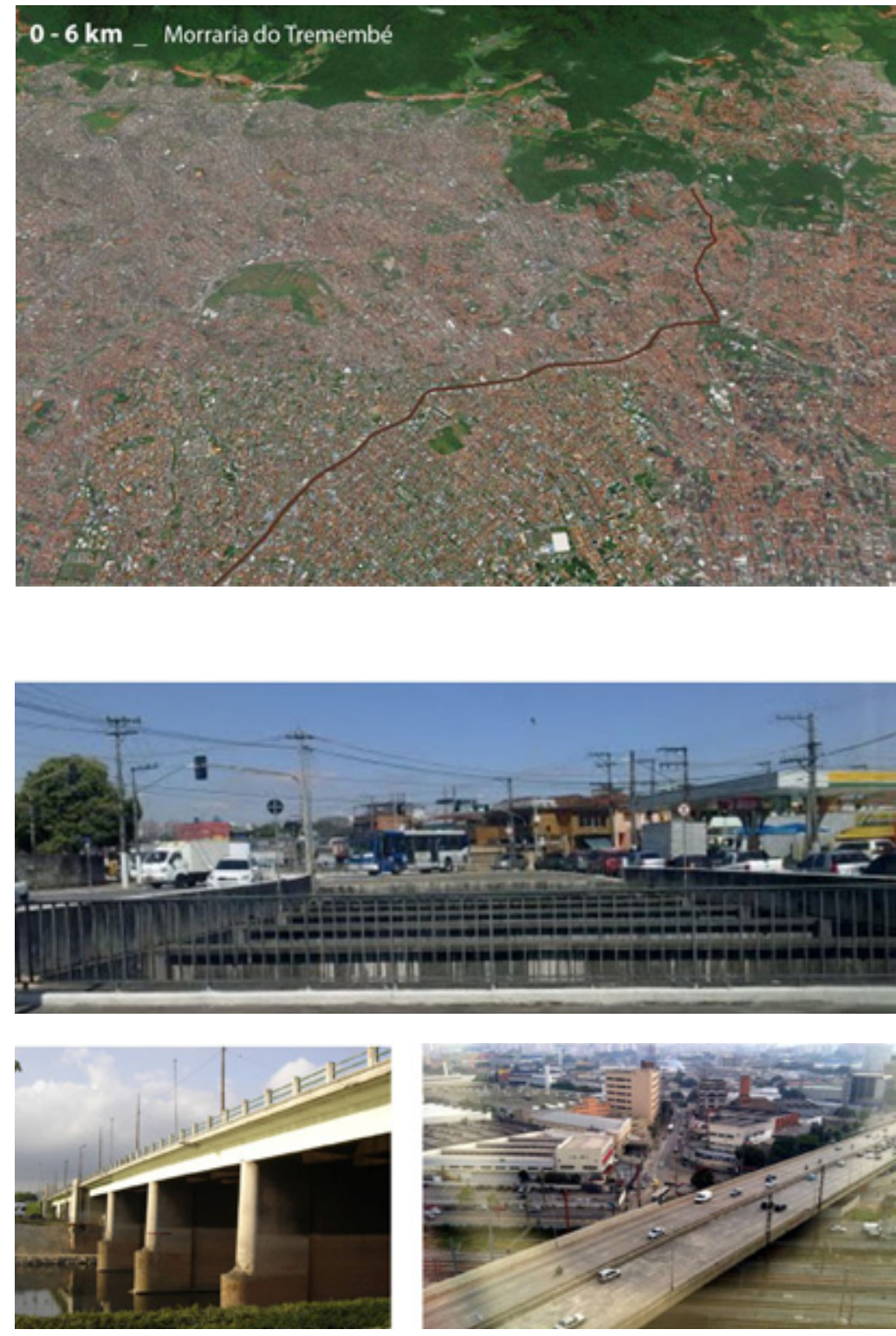

Figura 10 - Vista perspectivada do primeiro trecho da Trilha Norte-Sul. Fonte: Base do Google Earth e trabalho gráfico dos autores

Figura 11 - Vistas da Avenida Caetano Álvares, Ponte do Limão e Viaduto Antártica.

Fonte: Fotos Panoramio, Google Maps. 
A rota segue pela Avenida Ordem e Progresso, passando pela Ponte do Limão e, em seguida, encontrando o córrego Sumaré. No bairro industrial da Barra Funda, segue pela Avenida Antártica, cruza a Avenida Marquês de São Vicente, depois as infraestruturas da ferrovia pelo viaduto Antártica e se encontra com a Avenida Sumaré. $O$ trajeto de bicicleta ao longo desta Avenida usa a ciclovia já instalada no canteiro central, que é amplamente utilizada pela população ao longo do bairro das Perdizes. O córrego Sumaré está oculto em todo seu trajeto.

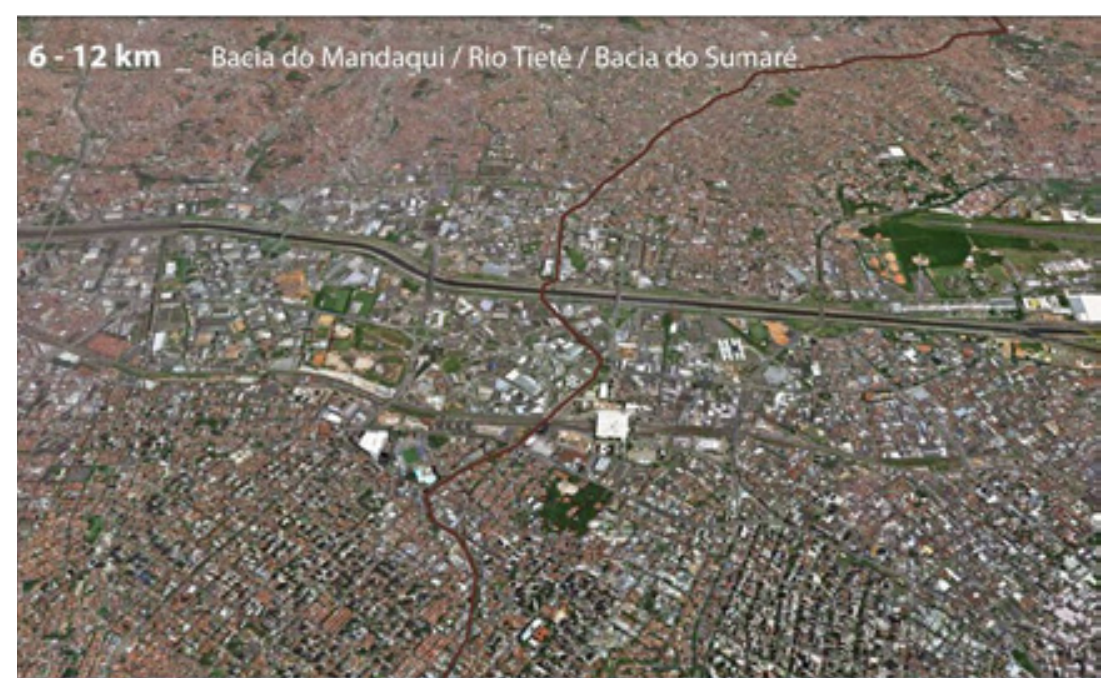

Figura 12 - Vista perspectivada do trecho intermediário Fonte: Base do Google Earth e trabalho gráfico dos autores

A trilha segue por baixo do metrô Sumaré, cruzando o espigão da Paulista, hoje inexistente. Este espigão servia de antigo divisor das águas entre Tietê e Pinheiros e era onde estavam localizadas as nascentes de vários córregos, inclusive do Sumaré. Continua em direção da Avenida Paulo VI, obedecendo de maneira aproximada o trajeto original do Córrego Verde. Passa perto do Cemitério São Paulo e encontra a Rua Henrique Schaumann. E, no seu trecho final, se prolonga pela Avenida Brasil e desemboca finalmente no Parque do Ibirapuera. 

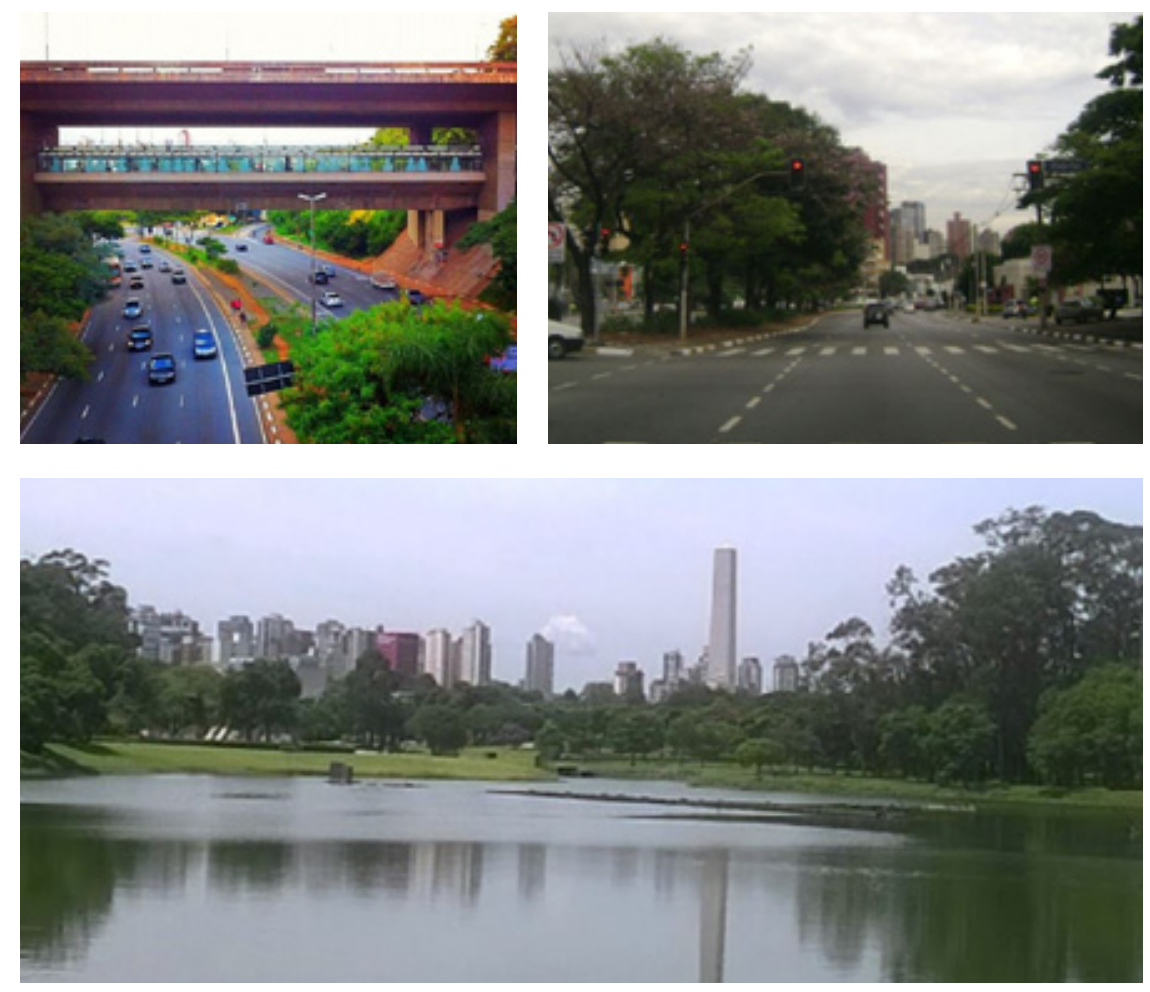

Figura 13 - Av. Sumaré (antigo espigão), Av. Brasil e Parque do Ibirapuera. Fonte: Fotos Panoramio Google Maps.

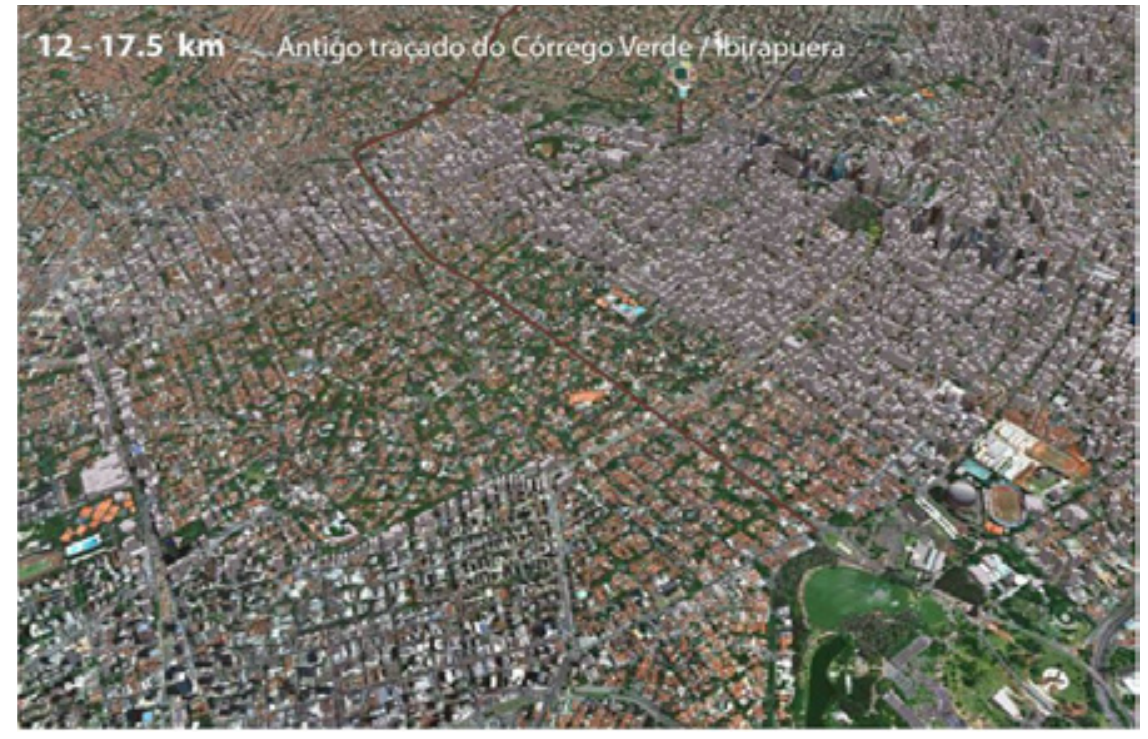

Figura 14 - Vista perspectivada do trecho final Fonte: Base do Google Earth e trabalho gráfico dos autores

Através deste estudo é possível constatar que há heterogeneidades no percurso. Se analisarmos o perfil topográfico da trilha, podemos identificar a existência de compartimentos do relevo. Estes se relacionam com processos naturais, em especifico o das águas, que podem ser afetados se não houver um tipo de ocupação adequada. Junto ao Tietê, principalmente na várzea da Barra Funda, predomina um antigo tecido indus- 
trial em transformação para novas funções e adensamento. Em contrapartida, existe a necessidade de preservar índices de permeabilidade, onde as ciclovias podem ser integradas às áreas de preservação de superfície verde.

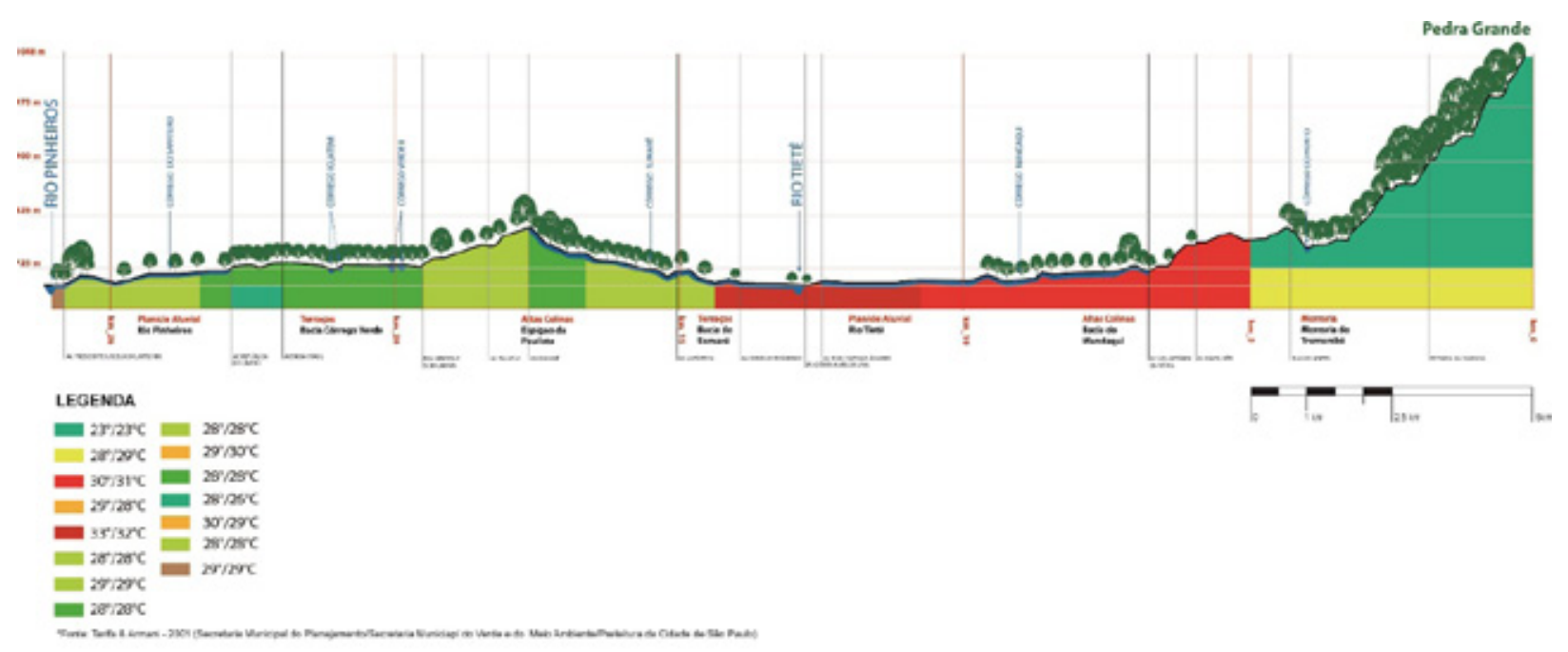

Figura 15 - Vista perspectivada do trecho intermediário

Fonte: Base do Google Earth e trabalho gráfico dos autores

Nos bairros de maior caráter residencial e pouca presença de indústria, existe um grande fluxo de pessoas circulando nos modais a pé e de bicicleta. Além disso, existe também a presença de alguma arborização. Por outro lado, os córregos das bacias do Sumaré e do Mandaqui estão canalizados e em sua maioria ocultos, e isso significa uma absoluta abstração da paisagem natural.

No último trecho, que atravessa as Avenida Henrique Schaumman e Brasil, enfrentase uma tipologia de viário alienada ao pedestre e do ciclista. As ruas não foram projetadas para o compartilhamento junto com outros modais não motorizados. 


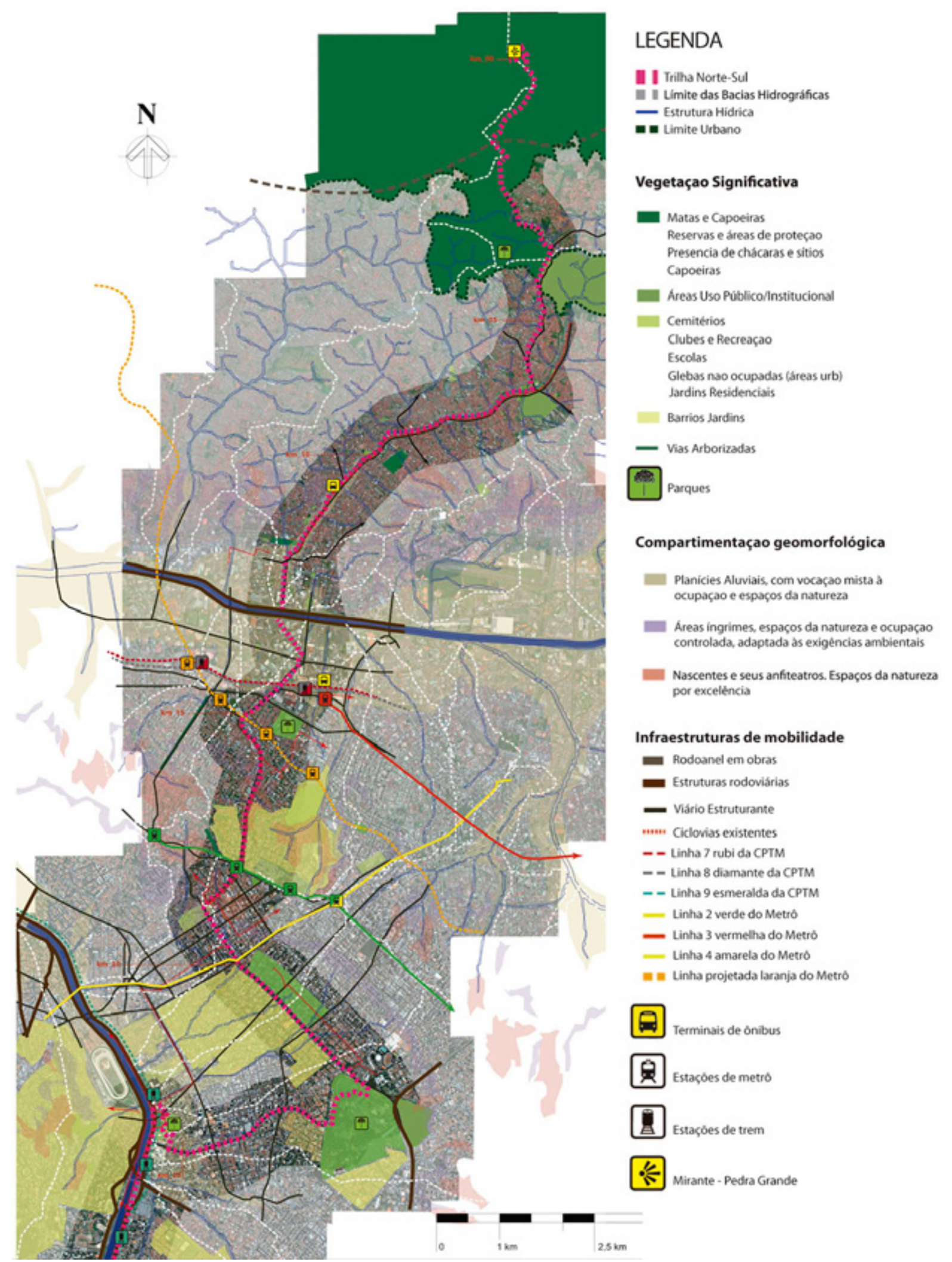

Figura 16 - Mapa da Trilha Norte-Sul com delimitação das bacias hidrográficas, estrutura hídrica, viária, transporte e vegetação significativa conforme a catalogação das tipologias verdes no livro "Vegetação Significativa do Município de São Paulo", elaborado pela Secretaria do Verde e Meio Ambiente da Prefeitura de São Paulo. Fonte: Elaboração gráfica dos autores. 


\section{CONSIDERAÇÕES FINAIS}

Diante de um panorama global da mobilidade urbana, vivenciado pelas grandes metrópoles do mundo, confrontamos grandes problemas relacionados aos deslocamentos viários causados pelo excesso de veículos motorizados particulares e pela falta de transporte público eficiente.

O reconhecimento das mudanças climáticas globais foi ganhando força a partir da década de 1970 e trouxe diversas propostas de ecologistas preocupados com o meio ambiente. As condições degenerativas da paisagem natural agravam-se principalmente nos países em desenvolvimento, ainda mais em grandes adensamentos urbanos, como São Paulo.

Parte desses gases poluentes provém dos veículos motorizados, portanto é pertinente destacar o que algumas cidades do mundo têm feito para buscar alternativas tanto para a questão atmosférica em alerta, como para a condição precária da mobilidade urbana nas grandes cidades, que vem trazendo consequências inevitáveis à qualidade de vida dos seus cidadãos. A bicicleta é, de fato, uma alternativa relevante e plausível como meio de transporte e amplamente utilizada em muitas cidades do planeta, pois vislumbra um tipo de locomoção que não é motorizada e, por isso, não causa mais prejuízos à atmosfera. No caso de Vancouver, por exemplo, ao menos $50 \%$ dos deslocamentos devem ser feitos em veículos não motorizados até 2020.

Cidades como São Paulo, em que a topografia, o clima e as distâncias podem, a princípio, ser empecilhos, apresentam diversas maneiras de viabilizar seus trajetos. As alternativas vão desde o exemplo já citado de São Francisco, onde as ciclovias foram alargadas, facilitando a passagem do ciclista desmontado em trechos excessivamente íngremes, ao caso de Trondheim na Noruega, onde foi instalado um pedal para tracionar o ciclista montado ladeira acima.

Enfrentamos um momento em que o planejamento urbano deve, por força, contemplar a gestão sustentável dos recursos naturais existentes no território para que o desenvolvimento das cidades seja possível a médio e longo prazo, sob o risco de colapso iminente caso essa variante não seja considerada.

O paradigma de desenvolvimento econômico vigente até o século XX passava pela exploração dos recursos naturais disponíveis sem limite. Para continuarmos crescen- 
do economicamente no contexto urbano existente, é necessário redefinir o uso da infraestrutura das cidades para que esta possa se aliar ao manejo sustentável dos recursos naturais, sua recuperação e manutenção (BELANGER, 2011). E as infraestruturas das ciclovias podem ser pensadas desta forma.

Incorporar a natureza à vida nas cidades significa que não podemos responder mais da forma como estávamos respondendo até agora com planejamentos rígidos que se sobrepõem ao meio natural. A utilização de conceitos da Infraestrutura Verde como forma de restauração do meio urbano atenderá tanto as demandas ambientais quanto as de transporte.

Estes benefícios podem ser explorados na Trilha Norte-Sul, se for associado à implantação da rede o projeto de melhoria ambiental da bacia hidrográfica urbanizada. Para isso, é necessário entender os compartimentos do relevo da bacia e alinhar com as ações para a recuperação das funções necessárias de cada setor. Desta forma, tanto nos fundos de vale ao longo do trajeto pela Avenida Sumaré e Avenida Engenheiro Caetano Álvares, quanto na área da antiga várzea do rio Tietê no bairro da Barra Funda, é importante pensar no projeto da ciclovia associada a Infraestrutura Verde como uma ferramenta para atender as exigências ambientais, entre as quais podemos destacar a restituição de verde, a possibilidade de implantação de parques, o desenho de estratégias para retenção e infiltração das águas e a arborização intensa das avenidas.

\section{BIBLIOGRAFIA}

ALCORTA, Arturo. A história da bicicleta no Brasil. São Paulo, 2014. Disponível em: <http://www.escoladebicicleta.com.br/historiabicicletaBrasilA.html>. Acesso em: 24 Abril 2015.

BÉLANGER, Pierre. 'Redefining Infrastructure'. In: MOSTAFAVI, Mohsen; DOHERTY, Gareth. 'Ecological Urbanism'. Graduate School of Design, Harvard University, p.332-349. 2011.

CET (Companhia de Engenharia de Tráfego). Bicicleta: Infraestrutura da cidade. Disponível em: <http://www.cetsp.com.br/consultas/bicicleta/infraestrutura-da-cidade. aspx> Acesso em: 07 maio 2015. 
CETESB (Companhia de Tecnologia de Saneamento Ambiental). Próclima - gases de efeito estufa. Disponível em: 10072014.

<http://www.cetesb.sp.gov.br/mudancas-climaticas/proclima/Efeito\%20Estufa/9-Gases\%20do\%20Efeito\%20Estufa>. Acesso em: 13 maio 2013.

CICLO VIVO. SP pode ter marginal subterrânea e parque linear no rio Tietê. 10 set. 2013. Disponível em: <http://ciclovivo.com.br/noticia/sp-pode-ter-marginalsubterranea-e-parque-linear-no-rio-tiete> Acesso em: 13 maio 2013.

DUANY, Andres; PLATER-ZYBERK, Elizabeth, JEFF, Speck. SuburbanNation: The RiseofSprawlandthe Decline ofthe American Dream. North Point Press, 2010, p. 88-94.

EL PAÍS. Brasil. Justiça acata pedido e paralisa construção de ciclovias em São Paulo.19 Março 2015. Disponível em: <http://brasil.elpais.com/brasil/2015/03/19/ politica/1426796542_323361.html>. Acesso em 12 Maio 2015.

EXAME.com.Ciclovia de $\mathbf{7 0}$ mil quilômetros ligara $\mathbf{4 3}$ países europeus. 07 set 2014. Disponível em: <http://exame.abril.com.br/mundo/noticias/ciclovia-de-70-milquilometros-ligara-43-paises-europeus>. Acesso em 13 Maio 2015.

FLATOUT- CONTESINI, Leonardo. Para incentivar vendas de carros, governo estuda mudanças no Código Civil.Disponível em: <http://www.flatout.com.br/ para-incentivar-vendas-de-carros-governo-estuda-mudancas-no-codigo-civil/.>. Acesso em: 13 Maio 2015.

FOLHA DE SÃO PAULO. RODRIGUES, Artur. Ministério Público entra com ação na Justiça para barrar ciclovias em SP. Cotidiano. 18 Março 2015. Disponível em: <http://www1.folha.uol.com.br/cotidiano/2015/03/1604710-promotoria-entra-comacao-para-barrar-ciclovias-em-sp.shtml>. Acesso em: 11 Maio 2015.

FOLHA DE SÃO PAULO. ROLNIK, Raquel. Cidades, bicicletas e protestos. São Paulo, 15 Abril 2015. Disponível em:

<http://www1.folha.uol.com.br/colunas/raquelrolnik/2015/04/1612747-cidadesbicicletas-e-protestos.shtml>. Acesso em 22 abril 2015.

FRANCO, Maria de Assunção Ribeiro. Planejamento ambiental para a cidade sustentável. São Paulo: Annablume: FAPESP, 2000. 
HART, Stanley; SPIVAK, Alvin. The Elephant in theBedroom: AutomobileDependenceandDenial. Pasadena, California, 1993, p. 122. New Paradigm Books.

JOVEM PAN ONLINE. VICARI, Bruno. Passeatas de ciclístas pelados na Av. Paulista - Jovem Pan. 1606 2008. Disponível em: <https://www.google.com.br/\#q=\%E2\%8 0\%98Passeatas+de+cicl\%C3\%ADstas+pelados+na+Av.+Paulista\%E2\%80\%99>. Acesso em: 15 maio 2015.

LANGRENEY, Brigitte; RIOLI, Regina Q.B. Recuperação de Córregos Urbanos da Barra Funda como Contribuição para a Mobilidade Sustentável. In: Revista LabVerde. $n^{\circ}$ 6, v.5, p. 118-140, 2012. Disponível em: < http://www.revistas.usp.br/ revistalabverde/article/view/61510> Acesso em: 15 de Abril 2015.

MAGALHÃES, Aurélio. Ciclovias na Coréia do Sul. Disponível em:

$<$ https://atmagalhaes.wordpress.com/2015/02/09/ciclovias-na-coreia-do-sul/> Acesso em: 08 maio 2015.

MALATESTA, Maria Emelina B. A História dos estudos de bicicleta na CET. São Paulo: Companhia de Engenharia de Tráfego. 2012, p. 58 - (Boletim Técnico da CET, 50).

MALATESTA, Maria Ermelina B. A bicicleta nas viagens cotidianas do Município de São Paulo. São Paulo, 2014, pp. 15-30, 67, 230. Tese (Doutorado na área de Planejamento Urbano e Regional). FAU-USP.

MALATESTA, M. E. B. A bicicleta nas viagens cotidianas do Município de São Paulo. São Paulo, 2014, p. 25-6, Tese (Doutorado na área de Planejamento Urbano e Regional). FAU-USP.

MONTANER, Josep Maria. Depois do movimento moderno. Barcelona, Gustavo Gili, 2001.

NEW YORK (Cidade). The GreenwayPlan for New York City. New York, 1998.

NL CYCLING. HowtheDutchgottheircycle paths. 09 Outubro 2011. In THISBIG CITY.

NOBRE, Eduardo. A. C. A atuação do Poder Público na construção da cidade de São Paulo: a influência do rodoviarismo no urbanismo paulistano. In: SEMINÁ- 
RIO de História da Cidade e do Urbanismo, 11, 2010, Vitória. Anais do XI Seminário de História da Cidade e do Urbanismo. Vitória: UFES, 2010.

O ESTADO DE SÃO PAULO. RIBEIRO, Bruno. Prefeitura quer 16 mil vagas para bikes até 2016. Caderno Metrópole. 19 Março 2015.

O ESTADO DE SÃO PAULO. RIBEIRO, Bruno.Deixar a bike na rua exige uso corrente e de tranca em U. Caderno Metrópole. 19 Março 2015.

PREFEITURA DE SÃO PAULO. Uso diário da bicicleta como meio de transporte cresce 50\% em 2014. São Paulo, 19, set. 2014. Disponível em:

<http://www.capital.sp.gov.br/portal/noticia/3728> Acesso em: 07 maio 2015.

PREFEITURA DE SÃO PAULO. Plano de Mobilidade de São Paulo: Modo bicicleta. Disponível em: <http://www.prefeitura.sp.gov.br/cidade/secretarias/upload/chamadas/ planmobsp-rev002_1428005731.pdf> Acesso em: 07 maio 2015.

PROTOCOLO DE KYOTO. Campanha Energia. Green Peace. O Protocolo de Kyoto. Disponível em: <http://www.greenpeace.org.br/clima/pdf/protocolo_kyoto.pdf> Acesso em: 14 maio 2015.

PUGLIESE, Philip. Complete Streets providealltheelementsof multimodal Transportation. In: 19th NATIONAL TRAILS SYMPOSIUM. Chattanooga, Nov. 2008., p. 4. Disponível em: <http://www.americantrails.org/resources/trans/completestreets08. html>. Acesso em: 26 Abril 2015.

RODRIGUES, Igor. São Paulo e a guerra das ciclovias. 19 Setembro 2014. Disponível em: <http://thisbigcity.net/pt-br/sao-paulo-e-a-guerra-das-ciclovias/>. Acesso em 11 Maio 2015.

SÃO PAULO ABERTA. Contador de Ciclistas em Teste. Disponível em: <http:// saopauloaberta.prefeitura.sp.gov.br/index.php/iniciativa/contador-de-ciclistas/>. Acesso em: 14 maio 2015.

TAIYAB, Nadaa. Transportation in Mega-Cities: A local issue, a global question. In: The Frederick S.Pardee Center for theStudyoftheLonger-Range Future, p.8, nov 2008. Boston University. 
TEISEN, Thaís. Bikes e ônibus ganham prioridade em Plano de Mobilidade Urbana de SP. Redação Ciclo Vivo. Disponível em: <http://ciclovivo.com.br/mobile/noticia/ bikes-e-onibus-ganham-prioridade-em-plano-de-mobilidade-urbana-de-sp-10490>. Acesso em: 20 de abril 2015.

THE GREENEST POST. MIWA, Jessica. Coréia do Sul produz energia solar. Disponível em: <http://www.thegreenestpost.com/na-coreia-do-sul-ciclovia-produz-energiasolar/> Acesso em: 08 maio 2015.

THISBIG CITY. RODRIGUES, Igor. São Paulo e a guerra das ciclovias. 19 Setembro 2014. Disponível em: <http://thisbigcity.net/pt-br/sao-paulo-e-a-guerra-das-ciclovias/>. Acesso em 11 Maio 2015

VACCARI, Lorreine Santos; FANINI, Valter. 'Mobilidade Urbana'. Série de Cadernos Técnicos, Conselho Regional de Engenharia, Arquitetura e Agronomia do Paraná (CREA-PR), Paraná, 2011. 44p.

VANCOUVER (Cidade). Greenest City ActionPlan. Vancouver, 2014. 53p. 